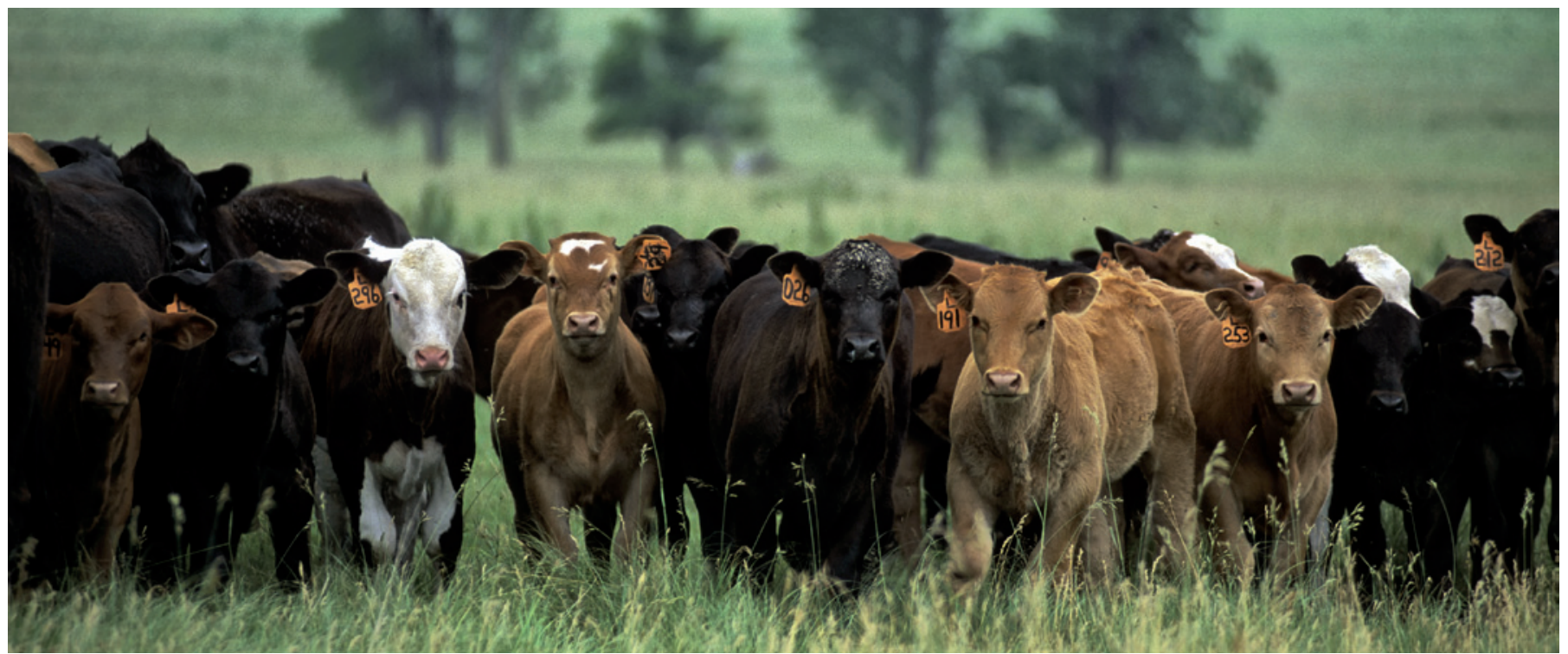

Livestock in the heart of US cattle country will be put at risk if foot-and-mouth disease escapes from the proposed National Bio and Agro-Defense Facility.

BIOSECURITY

\title{
Plans stall for biodefence lab
}

\section{US National Academy of Sciences reassesses risks of high-security work in cattle country.}

\section{BY SUSAN YOUNG}

$\mathrm{F}$ or Katharine Bossart, a trip to the lab can involve a 22-hour flight. Bossart, a microbiologist at Boston University in Massachusetts, works on treatments and vaccines for the Nipah and Hendra viruses, which are deadly to both horses and humans. Her research requires the highest level of biological security containment - BSL- 4 - but no BSL-4 labs in the United States can accommodate horses, so she collaborates with researchers in Australia.

"If we want to protect large animals from these infections, then we have to test vaccines in them," says Bossart.

The US Department of Homeland Security (DHS) has broken ground for a facility that would have allowed researchers such as Bossart to work closer to home. The National Bio and Agro-Defense Facility (NBAF) in Manhattan, Kansas, is designed to provide BSL-4 containment for large-animal studies and replace the Plum Island Animal Disease Center, the federal government's 58-year-old BSL-3 installation off Long Island in New York. But the NBAF's future has been thrown into question, with no new money allocated for it in the president's proposed 2013 federal budget and reviewers considering fears about whether it could keep pathogens safely contained in the middle of prime US cattle country.

Last week, the US National Academy of
Sciences (NAS) convened a closed meeting to review a revised risk assessment from the DHS, which it received on 10 February but has not yet made public. Congress ordered the report last year, after the NAS harshly criticized a 2010 assessment, citing factors such as the absence of back-up high-efficiency particulate filters in the building plans; flawed estimates of how quickly an outbreak could be detected and stopped; and poor consideration of the facility's proximity to metropolitan areas and livestock. Beef producers have been particularly alarmed that the 2010 assessment put the cumulative risk of foot-and-mouth disease escaping from the NBAF over the facility's projected 50-year lifespan at 70\% (see 'Fear

\section{FEAR FACTOR}

A 2010 risk assessment found that the probability of foot-and-mouth disease escaping from the National Bio- and Agro-Defense Facility during its 50 year lifespan was $70 \%$.

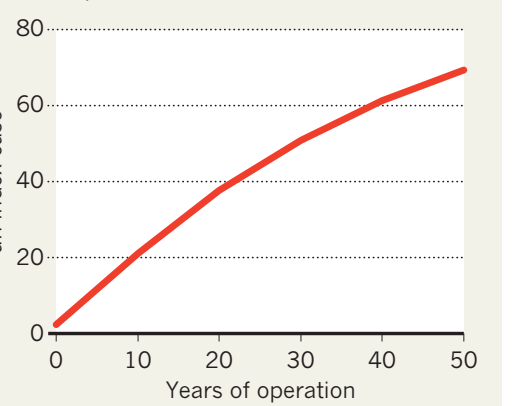

factor'). The virus that causes the disease spreads quickly and would have a devastating effect on the US cattle industry if it escaped. US research with live foot-and-mouth virus is currently restricted to Plum Island.

Both the latest assessment and the review of it by the NAS, expected by June, are required by Congress before the US $\$ 50$ million designated for the NBAF in the 2012 federal budget can be spent.

The 2013 budget not only commits no further funds to the NBAF, but also creates a new hurdle, requiring the NAS to examine whether current disease threats justify the facility, which could cost up to $\$ 1$ billion to build.

"We understood going into this that issues would arise," says Ron Trewyn, vice-president for research at Kansas State University (KSU) in Manhattan, which in 2009 helped the state to win its bid to host the NBAF. "Budget is a big deal these days, but given the importance of the NBAF to national security and to protecting our agricultural economy, we are confident that these issues will be worked through and it will move forward."

Kansas has committed \$105 million in bonds to support the facility, which is touted as an economic boon for the state. The site is adjacent to the KSU Biosecurity Research Institute, a BSL-3 facility that studies animal and plant pathogens. The university is now

\section{DNATURE.COM}

For more on science and the 2013 US

budget, see:

go.nature.com/twcupo 
considering whether to send graduate students to Plum Island to build expertise. "We are working with Homeland Security and the US Department of Agriculture on Plum Island to develop the workforce that will ultimately work at the NBAF," says Stephen Higgs, director of the Biosecurity Research Institute.

But critics of the facility welcomed the decision by President Barack Obama's administration not to request further funding for it. "We are optimistic," says Tom Manney, a retired KSU biophysicist who helps to lead a group called No NBAF in Kansas. The group says that a facility that works on highly infectious animal diseases does not belong "in the centre of the foodanimal health corridor".

Opponents voiced their concerns about the project at an NAS public meeting in Manhattan in January. "It is easy for those promoting the facility to argue for the Kansas site because their livelihoods are not at stake," wrote cattle rancher Paul Irvine in a submitted statement.

What happens next will depend, in part, on the NAS's judgement of the facility's risks and benefits. The DHS says that the NBAF is needed to develop countermeasures against bioterrorism - a threat that resonates less now than it did immediately after the anthrax attacks on the United States in 2001. But the department also cites three threats that receive far less public attention. One is the growing likelihood of foreign animal diseases entering the United States as a result of international animal movement from commerce and smuggling. A second is the risk of animal-borne diseases spreading to humans as population growth and dispersal puts people into greater contact with wild animals. The third is the potential for global warming to expand the range of insect-borne diseases.

"Not having a facility like this is almost negligent," says Higgs. "We have the capabilities to build a facility that will better prepare us in the event of some pathogen coming in. The NBAF will be the shining star in these types of labs."

Soren Alexandersen, director of a BSL-4 facility in Winnipeg, Canada, that can accommodate small numbers of livestock, says that the challenges of running such labs can be met with technical measures. He adds that although many of the diseases studied in Winnipeg, including the Nipah Virus, are not currently found in North America, preparedness matters. "We have the methods and the facility in place so that we can start working," he says.

Bossart agrees. "You can't just flip a switch and make these facilities function," she says. "If you don't have these unique capabilities, you are not going to be able to respond if an outbreak occurs." -

\section{FUNDING}

\section{US disease agency in fiscal peril}

\section{Proposed budget changes threaten disease prevention and surveillance programmes.}

\section{BY MEREDITH WADMAN}

$\mathrm{W}$ hen US President Barack Obama proposed a US\$664-million cut in congressional funding for the US Centers for Disease Control and Prevention (CDC) in his 2013 budget request, he tried to ease the pain by replacing much of it with money from other sources. But only days after the 13 February request, a vote on Capitol Hill made clear just how vulnerable those substitutions are, suggesting that the US public-health agency is on increasingly shaky financial ground.

The proposed cut would come from the part of the agency's budget that is controlled by Congress and pays for the core operations of the CDC, based in Atlanta, Georgia. These include grants to local, county and state public-health departments to monitor infectious diseases or track food-borne outbreaks. Core funding is also used to maintain the Strategic National Stockpile, a repository of drugs reserved for fighting epidemics and bioterrorism. If Obama's plan is enacted, the CDC's congressionally controlled funding will have fallen by roughly $20 \%$ since 2010 - a decline that "looks like a disaster waiting to happen", says Scott Becker, executive director of the Association of Public Health Laboratories in Silver Spring, Maryland.

\section{CUT TO THE CORE}

The budget of the US Centers for Disease Control and Prevention $(C D C)$ is increasingly floating on funds that may not materialize.

- Prevention and Public Health Fund

Transfers from other agencies

(requires approval by Congress)

Core programme funding

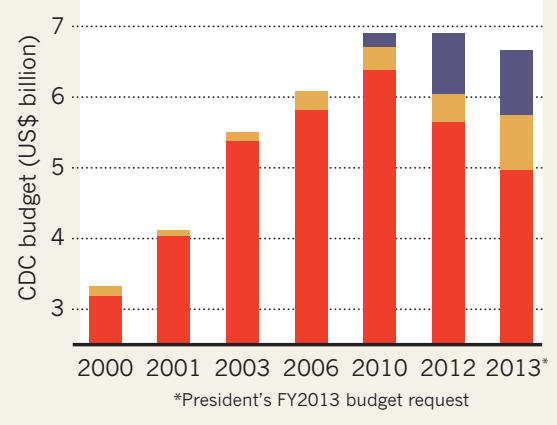

Cuts to the CDC have already contributed to the loss of nearly 50,000 jobs in state and local health departments since 2008. This year, the administration argues that "efficiencies" will make possible the specific cuts it has proposed in areas such as adult-immunization funding and epidemiological support. But CDC advocates and public-health officials are sceptical. A proposed \$47-million cut to the Strategic National Stockpile "is a lot more than just efficiency. It's going to cut capability as well," says Crystal Franco, an associate with the Center for Biosecurity of UPMC in Baltimore, Maryland. "We are reaching the tipping point where preparedness efforts are going to be reversed because of the lack of funding," she adds.

The CDC's budget was significantly boosted a decade ago because of concerns over bioterrorism in the wake of the $9 / 11$ attacks. But as a budget vice tightens on the US government, the administration has begun to rely on two other sources to offset cuts to CDC programmes that have historically been funded by Congress (see 'Cut to the core').

One source is transfer payments made to the CDC from other public-health agencies. The 2013 budget would boost those payments by $\$ 296$ million over this year's level. But that would require congressional approval, which is far from guaranteed.

The second source of funds to offset CDC cuts — \$903 million from the Prevention and Public Health Fund (PPHF) - could be even less secure. Established by the 2010 health-reform law, the multibillion-dollar fund is aimed at disease prevention but has become an object of disdain for those opposed to the law. In the current atmosphere of fiscal constraint, the PPHF has become a target for raiding, and already, as part of a payroll-tax-cut extension that was signed into law by Obama on 22 February, Congress has cut the fund by $20 \%$, or $\$ 250$ million, in 2013 , and by a total of $\$ 6.25$ billion to 2025 .

The fund "is vulnerable. It could go away quickly," says James Hughes, a CDC veteran and immediate past president of the Infectious Diseases Society of America in Arlington, Virginia. What's more, says Hughes, now a professor of public health at Emory University in Atlanta, the fund was intended to launch innovative prevention initiatives, "not to replace core public-health capacity support”. 